\title{
West Nile Virus Lineage 2 in Horses and Other Animals with Neurologic Disease, South Africa, 2008-2015
}

\author{
Marietjie Venter, Marthi Pretorius, \\ James A. Fuller, Elizabeth Botha, \\ Mpho Rakgotho, Voula Stivaktas, \\ Camilla Weyer, Marco Romito, June Williams
}

During 2008-2015 in South Africa, we conducted West Nile virus surveillance in 1,407 animals with neurologic disease and identified mostly lineage 2 cases in horses $(7.4 \%$, $79 / 1,069)$, livestock $(1.5 \%, 2 / 132)$, and wildlife $(0.5 \%$, $1 / 206$ ); $35 \%$ were fatal. Geographic correlation of horse cases with seropositive veterinarians suggests disease in horses can predict risk in humans.

$\mathrm{W}^{\mathrm{s}}$ est Nile virus (WNV) circulates between ornithophilic mosquitoes and birds. Birds are used as WNV sentinels, but in Africa, birds rarely die of infections, probably because of genetic resistance (1). Therefore, another animal is needed to predict risk for WNV disease in Africa. Humans and horses are considered incidental dead-end hosts for WNV (2). Although $\approx 20 \%$ of infections in these species are symptomatic, $\approx 1 \%$ of human cases involve neurologic disease, with $1 \%-10 \%$ fatality rates (3), but $90 \%$ of horse cases involve neurologic disease, with 30\%-40\% fatality rates (4). Monitoring equine populations living near human populations might enable prediction of human outbreaks in Africa (5).

WNV is endemic to South Africa (1). The largest human outbreak occurred in 1974 in Karoo (1); during 1983-1984, a smaller epizootic outbreak occurred in Witwatersrand (Gauteng Province) (6). During 2010-2011, screening of the cerebrospinal fluid of patients in hospitals in Gauteng Province indicated WNV was present in 3.5\% of unsolved cases of neurologic disease, suggesting severe WNV cases might be missed because of a lack of clinical awareness of the pathogenic potential of this virus (7).

Author affiliations: University of Pretoria Centre for Viral Zoonoses, Pretoria, South Africa (M. Venter, M. Pretorius, E. Botha, M. Rakgotho, V. Stivaktas, J. Williams); US Centers for Disease Control and Prevention, Global Disease Detection Centre, Pretoria (M. Venter, J.A. Fuller); National Health Laboratory Service, Tshwane, South Africa (M. Pretorius); University of Pretoria Equine Research Centre, Pretoria (C. Weyer); Onderstepoort Veterinary Research, Onderstepoort, South Africa (M. Romito)

DOI: https://doi.org/10.3201/eid2312.162078
WNV isolates are divided into 2 lineages (8): lineage 1, which predominates in the Northern Hemisphere and Australia, and lineage 2, which is endemic to southern Africa and Madagascar and started emerging in central Europe in 2008 (9). Lineage 2-associated encephalitis outbreaks have been occurring in Greece since 2010, causing hundreds of neurologic cases in humans (fatality rate 17\%) and horses (3). Lineage 2 was first associated with severe neurologic disease in horses in South Africa in 2009 (8). Neurologic signs of infection in horses are similar for both lineages and include ataxia, weakness, recumbence, seizures, and muscle fasciculation $(8,10)$. However, epidemiologic data are lacking.

South Africa conducts active surveillance for infectious pathogens in horses, such as African horse sickness virus (AHSV), to help the horse industry maintain diseasefree status, as required by the World Organisation for Animal Health. Equine WNV is also a World Organisation for Animal Health-listed disease, enabling researchers to use horses for WNV surveillance internationally. To assist with predicting WNV human cases and managing outbreaks in susceptible animals, we sought to define the epidemiology of WNV in horses in South Africa.

\section{The Study}

We prospectively investigated horses and other animals with fever or neurologic signs during 2008-2015 and compared the geographic range of WNV-positive animals with that of WNV-seropositive veterinarians involved in equine, wildlife, and livestock disease management during 2011-2012 (11). A total of 210 veterinarians from all 9 South Africa provinces submitted blood, neurologic tissue, and visceral tissue specimens from horses (acquired during 2008-2015) and wildlife and livestock (acquired during 2010-2015) that displayed acute fever, neurologic disease, or other signs of acute infection, accompanied by their demographic and disease data, to the Centre for Viral Zoonoses, University of Pretoria (Pretoria, South Africa). A total of 1,407 samples $(64 \%$ blood/serum, $25 \%$ tissue, $6 \%$ both blood/serum and tissue, $4 \%$ viral RNA) were received.

We tested all specimens for WNV, Shuni virus, alphaviruses, and equine encephalitis virus and submitted samples for rabies virus testing, if suspected, to Onderstepoort Veterinary Research, Onderstepoort, South Africa, as previously 
Table 1. WNV infection, co-infection, disease, and death in horses, by year, South Africa, 2008-2015*

\begin{tabular}{|c|c|c|c|c|c|c|c|c|c|}
\hline \multirow[b]{2}{*}{ Category } & \multicolumn{9}{|c|}{ No. (\%) horses } \\
\hline & 2008 & 2009 & 2010 & 2011 & 2012 & 2013 & 2014 & 2015 & Total \\
\hline Total specimens & 71 & 76 & 150 & 164 & 89 & 138 & 193 & 188 & 1,069 \\
\hline Confirmed WNV positive† & $9(12.7)$ & $6(7.9)$ & $18(12.0)$ & $12(7.3)$ & $3(3.4)$ & $4(2.9)$ & $23(11.9)$ & $4(2.1)$ & $79(7.4)$ \\
\hline WNV PCR positive† & $5(7.0)$ & $3(3.9)$ & $8(5.3)$ & $2(1.2)$ & $0(0)$ & $1(0.7)$ & $4(2.1)$ & $1(0.5)$ & $24(2.2)$ \\
\hline WNV IgM positive† & $5(7.0)$ & $3(3.9)$ & $12(8.0)$ & $10(6.1)$ & $3(3.4)$ & $3(2.2)$ & $20(10.4)$ & $3(1.6)$ & $59(5.5)$ \\
\hline Deathsł & $5(55.6)$ & $3(50.0)$ & $8(44.4)$ & $3(25.0)$ & $1(33.3)$ & $1(25.0)$ & $5(21.7)$ & $1(25.0)$ & $27(34.2)$ \\
\hline Any neurologic signs $\ddagger$ & $8(88.9)$ & $6(100.0)$ & $16(88.9)$ & $11(91.7)$ & $2(66.7)$ & $4(100.0)$ & $21(91.3)$ & $4(100.0)$ & 72 (91.1) \\
\hline Feverł & $2(22.2)$ & $2(33.3)$ & $3(16.7)$ & $6(50.0)$ & 1 (33.3) & $1(25.0)$ & $10(43.5)$ & $3(75.0)$ & $28(35.4)$ \\
\hline Co-infections $\ddagger$ and co- & 2 (22.2), & 2 (33.3), & $1(5.6)$ & 2 (16.7), & 2 (66.7), & 0 & 4 (17.4), & $1(25.0)$ & 14 (17.7), \\
\hline infecting viruses & 2 AHSV & 2 SINV & 1 SHUV & 2 MIDV & $\begin{array}{l}1 \text { AHSV, } \\
1 \text { SINV }\end{array}$ & & $\begin{array}{c}2 \text { MIDV, } \\
1 \text { SHUV, } \\
1 \text { EEV }\end{array}$ & 1 SHUV & $\begin{array}{c}3 \text { AHSV, } \\
3 \text { SINV, } \\
3 \text { SHUV, } \\
4 \text { MIDV, } \\
1 \text { EEV }\end{array}$ \\
\hline
\end{tabular}

*AHSV, African horse sickness virus; EEV, equine encephalitis virus; MIDV, Middleburg virus; SHUV, Shuni virus; SINV, Sindbis virus; WNV,

West Nile virus.

†Percentage of total number of specimens tested.

łPercentage of total number of confirmed WNV-positive cases. Confirmed cases were those that tested positive by PCR plus those that tested positive by WNV IgM Capture ELISA (IDEXX Laboratories, Montpellier, France) followed by neutralization assay.

described (12). All WNV-positive cases were tested for AHSV (13). We screened all equine serum and plasma specimens for WNV IgM (WNV IgM Capture ELISA Test; IDEXX Laboratories, Montpellier, France) and confirmed by neutralization assay (8). Reverse transcription PCR-positive cases were sequenced (GenBank accession nos. KY176717-36) and subjected to maximum likelihood analysis (online Technical Appendix Figure, https://wwwnc. cdc.gov/EID/article/23/12/16-2078-Techapp1.pdf). We compared WNV positivity with clinical signs in horses by logistic regression using crude odds ratios (ORs) and adjusted ORs (aORs) with 95\% CIs (Stata 14; StataCorp LLC, College Station, Texas, USA) (online Technical Appendix Table).

Most clinical cases were in horses $(76.0 \%$, $1,069 / 1,407)$, followed by wildlife $(14.6 \%, 206 / 1,407)$ and livestock $(9.4 \%, 132 / 1,407)$. We detected most WNV cases in horses $(7.3 \%, 79 / 1,069 ; \mathrm{p}<0.001)$, and $1(0.5 \%)$ case in wildlife (imported North American white-tailed deer [Odocoileus virginianus]), and 2 in (1.5\%) livestock (locally bred Ayreshire cow [Bos taurus], boer goat [Capra aegagrus hircus]).

Real-time PCR results were positive for 24 cases; 20 isolates could be sequenced, and 18 clustered with lineage 2 (online Technical Appendix Figure). A mare and her miscarried fetus were the only animals infected with lineage 1 viruses (14). We detected 14 (17.7\%) co-infections in WNV-infected horses (Table 1), with high fatality rates for most co-infecting viruses: MIDV $(100 \%, 4 / 4)$; AHSV (66.7\%, 2/3); SINV (100\%, 3/3); Shuni virus $(33.3 \%, 1 / 3)$; and equine encephalitis virus $(0 \%, 0 / 1)$.

Most (77.2\%) WNV cases occurred in Southern Hemisphere autumn (March-May) (Figure 1), 2-3 months after peak precipitation. The interannual detection rate among horses was 2.1-12.7\% (Table 1). Most specimens came from Gauteng $(n=400)$ and Western Cape $(n=296)$ Provinces (Figure 2, panel A). Most WNV-positive cases were from Gauteng Province $(7.3 \%, 29 / 400)$, but detection rates were highest in Northern Cape (10.2\%) and Eastern Cape

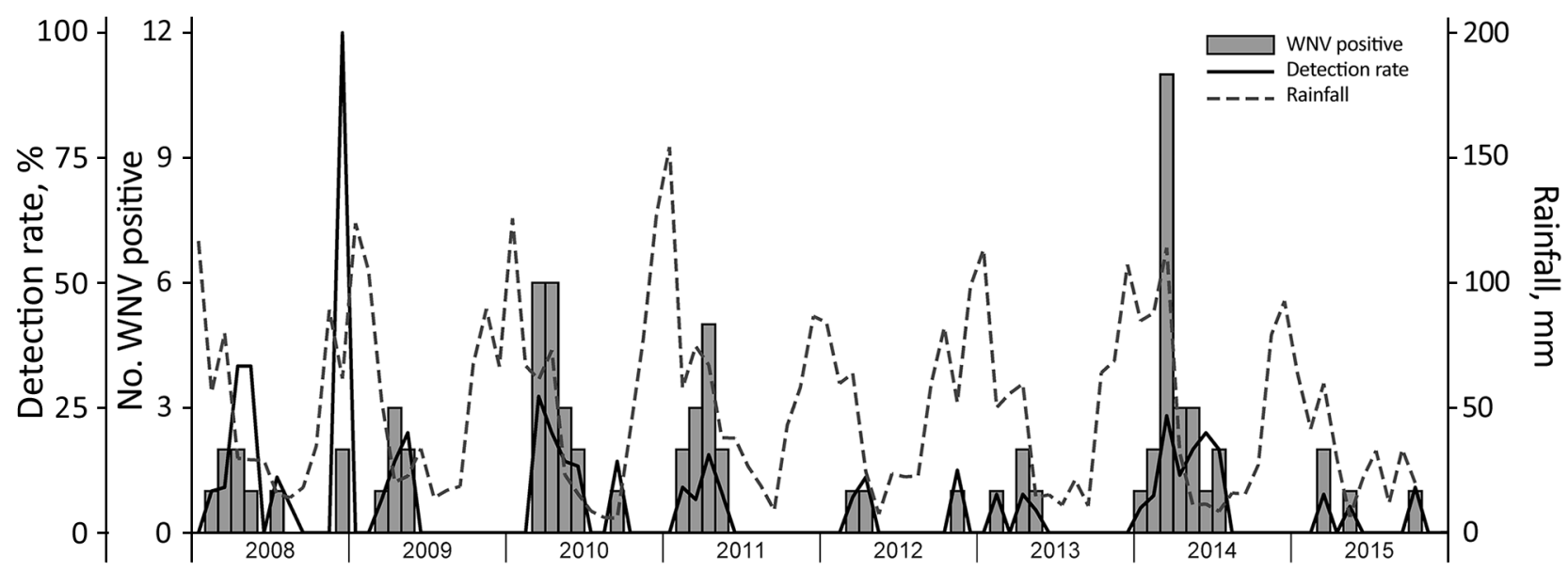

Figure 1. Seasonal occurrence of WNV in horses, South Africa, 2008-2015. Rainfall levels are indicated as a potential correlate for increases in the prevalence of the WNV mosquito vector Culex univitattus. WNV, West Nile virus. 


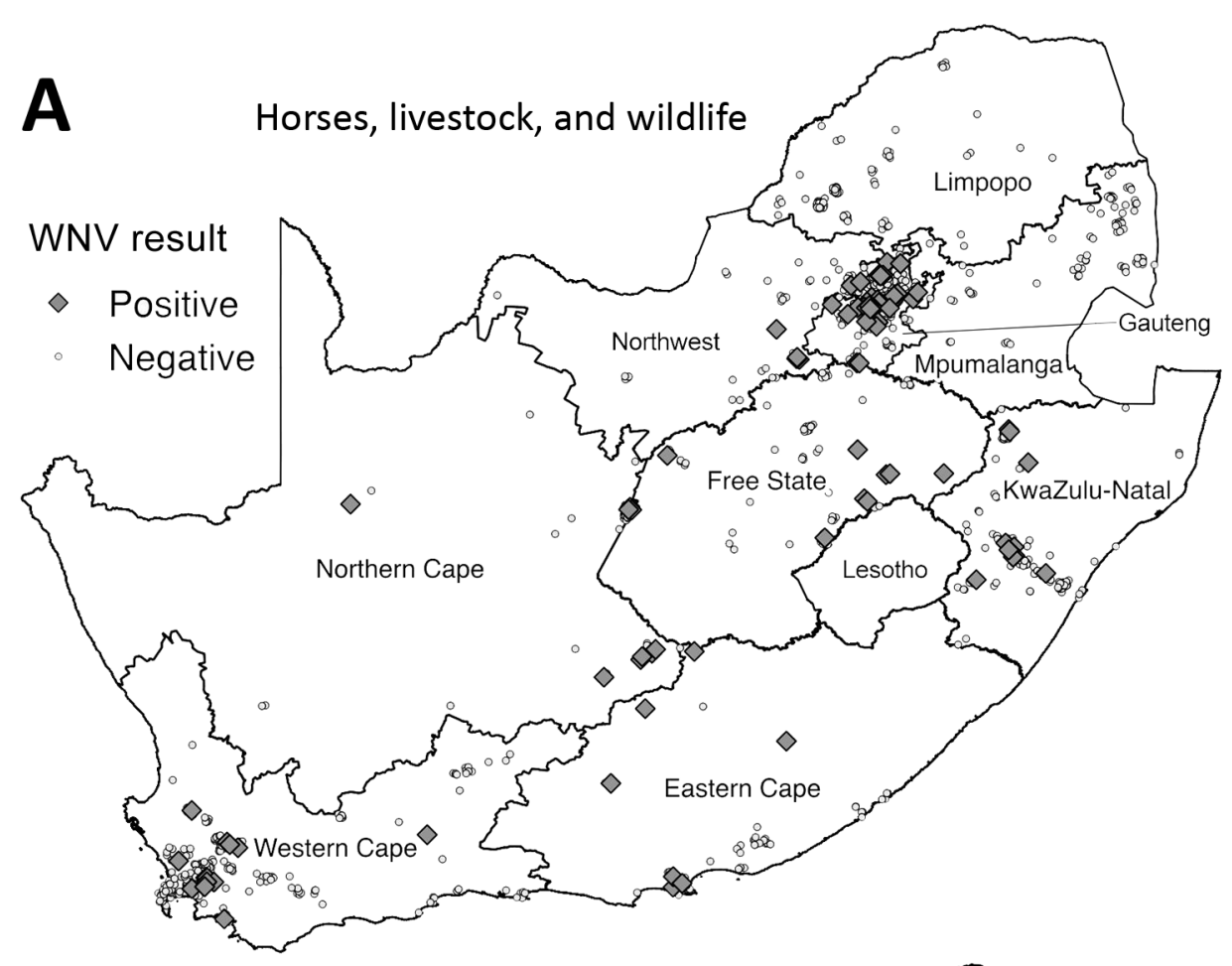

Figure 2. Distribution of WNV cases among horses, livestock animals, and wildlife species during 2008-2015 and of WNV neutralizing antibody-positive veterinarians involved in equine, wildlife, and livestock disease management during 2011-2012, South Africa. A) Samples were collected from horses during 2008-2015 and from livestock and wildlife 2010-2015. Samples were considered positive if they tested positive for WNV genome by PCR or for WNV IgM by WNV IgM Capture ELISA (IDEXX Laboratories, Montpellier, France) and WNV neutralizing antibody by neutralization assay. B) Distribution of veterinarians described in previous report (11). Human serum was considered positive if virus neutralization was observed at a titer of 1:10 and higher. WNV, West Nile virus.

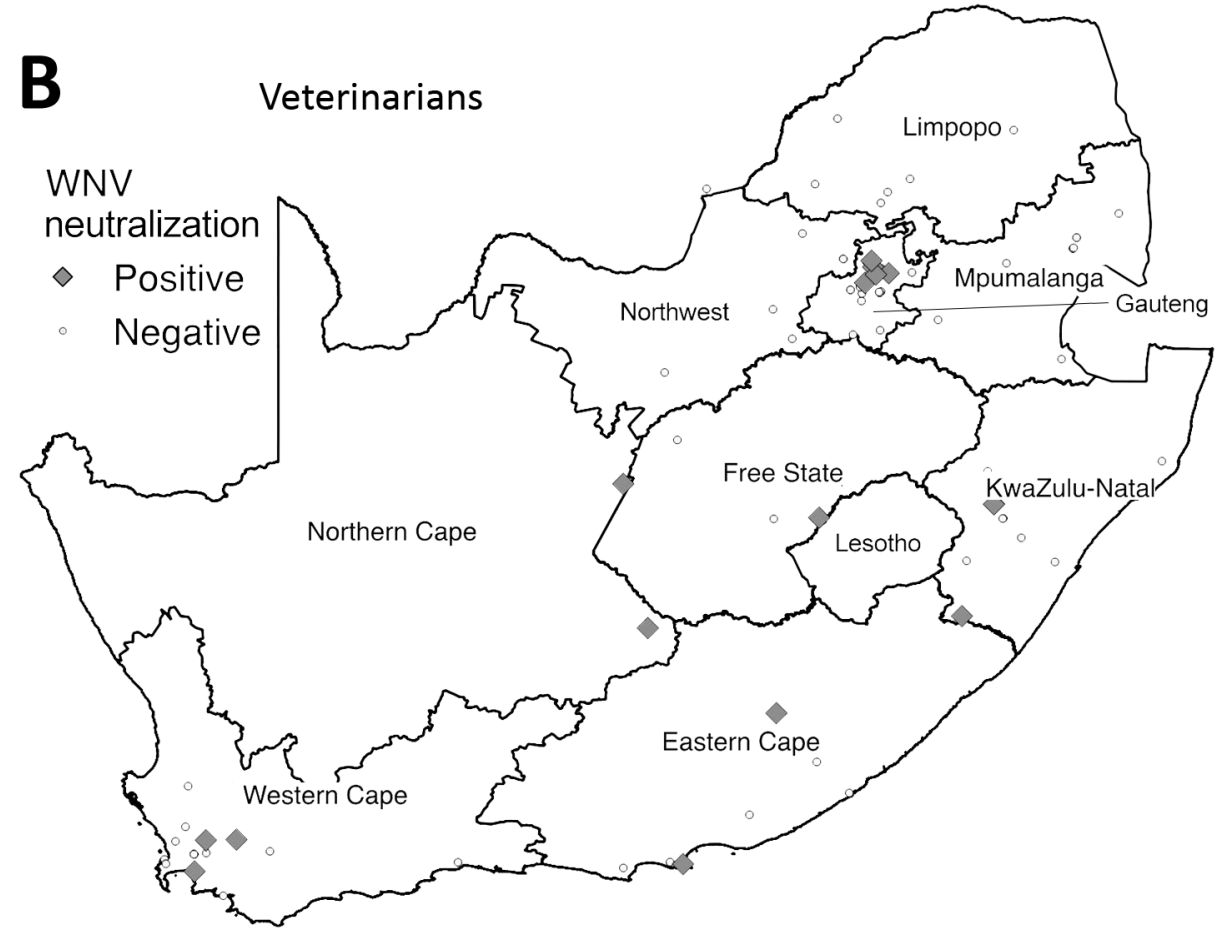

(10.5\%) Provinces. Of 152 samples from Limpopo and Mpumalanga Provinces, 99 of which came from wildlife species, none were WNV positive. The geographic distribution of WNV-seropositive veterinarians (11) was similar to that of WNV-positive horses (Figure 2 panel B).

Older horses $(\geq 15$ y) were least likely $(4.9 \%, 3 / 61)$ and 1-4-year-old horses most likely $(41.0 \%, 25 / 61)$ to test
WNV positive (Table 2); 35.4\% of WNV-positive horses were febrile, $93.7 \%$ displayed neurologic signs, and $34.2 \%$ died. WNV-associated signs included ataxia, paralysis, paresis, seizures, and tongue paralysis. Multiple logistic regression models (online Technical Appendix Table) confirmed neurologic signs as a strong predictor (aOR 4.12, 95\% CI 1.59-10.70) and fever a weak predictor (aOR 1.25, 
West Nile Virus Lineage 2 in Horses, South Africa

Table 2. Characteristics of 1,069 horses positive and negative for WNV infection, South Africa, 2008-2015*

\begin{tabular}{|c|c|c|c|}
\hline \multirow[b]{2}{*}{ Variable } & \multicolumn{2}{|c|}{ No./total (\%) } & \multirow[b]{2}{*}{ Crude OR $(95 \% \mathrm{Cl})$} \\
\hline & WNV negative, $\mathrm{n}=990$ & WNV positive, $\mathrm{n}=79$ & \\
\hline \multicolumn{4}{|c|}{ Detection method and result } \\
\hline PCR+ IgM- & NA & 20/79 (25.3) & \\
\hline PCR- IgM+ & NA & $55 / 79(69.6)$ & \\
\hline PCR+ IgM+ & NA & $4 / 79(5.1)$ & \\
\hline \multicolumn{4}{|l|}{ Age, y† } \\
\hline$<1$ & $64 / 617(10.4)$ & 6/61 (9.8) & 1.00 (Reference) \\
\hline $1-4$ & $170 / 617(27.6)$ & $25 / 61(41.0)$ & $1.57(0.62-4.00)$ \\
\hline $5-9$ & $152 / 617(24.6)$ & $15 / 61(24.6)$ & $1.05(0.39-2.84)$ \\
\hline $10-14$ & $145 / 617(23.5)$ & $12 / 61(19.7)$ & $0.88(0.32-2.46)$ \\
\hline$\geq 15$ & $86 / 617(13.9)$ & $3 / 61(4.9) \ddagger$ & $0.37(0.09-1.54)$ \\
\hline Died or euthanized§ & 240/976 (24.6) & $27 / 79$ (34.2) & $1.59(0.98-2.59)$ \\
\hline Feverף & 389/981 (39.7) & 28/79 (35.4) & $0.84(0.52-1.35)$ \\
\hline \multicolumn{4}{|l|}{ Neurologic signs } \\
\hline Any neurologic sign\# & 785/990 (79.3) & 74/79 (93.7) & $3.86(1.54-9.68)$ \\
\hline Ataxiaף & $249 / 981(25.4)$ & $21 / 79$ (26.6) & $1.06(0.63-1.79)$ \\
\hline Paralysis $\uparrow$ & $67 / 981(6.8)$ & $10 / 79$ (12.7) & $1.98(0.97-4.01)$ \\
\hline Paresis ${ }^{* \star}$ & $71 / 980(7.2)$ & 13/79 (16.5) & 2.52 (1.33-4.79) \\
\hline Recumbent & $105 / 981(10.7)$ & $6 / 79(7.6)$ & $0.69(0.29-1.62)$ \\
\hline Seizureף & $35 / 981(3.6)$ & $4 / 79(5.1)$ & $1.44(0.50-4.16)$ \\
\hline Tongue paralysis $\mathbb{T}$ & $5 / 981(0.5)$ & $2 / 79(2.5)$ & $5.07(0.97-26.56)$ \\
\hline \multicolumn{4}{|l|}{ Other signs } \\
\hline Anorexiađ & $132 / 981(13.5)$ & $6 / 79(7.6)$ & $0.53(0.23-1.24)$ \\
\hline Icterus $^{* *}$ & $63 / 980(6.4)$ & $8 / 79(10.1)$ & $1.64(0.76-3.56)$ \\
\hline Rectal prolapseף & $6 / 981(0.6)$ & $2 / 79(2.5)$ & $4.22(0.84-21.27)$ \\
\hline \multicolumn{4}{|c|}{ 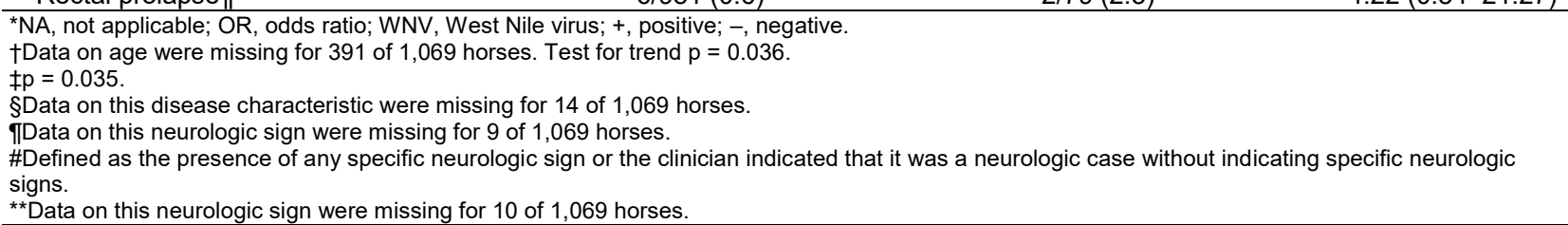 } \\
\hline
\end{tabular}

95\% CI $0.75-2.06)$ of WNV positivity. Paresis (aOR 2.74, 95\% CI 1.30-5.79) and tongue paralysis (aOR 7.73, 95\% CI 1.27-47.18) were both predictive of WNV positivity.

\section{Conclusions}

This 8-year surveillance confirmed annual WNV outbreaks among horses in South Africa, most cases being lineage 2. The neurologic signs and fatality rate among WNV lineage 2-infected horses correlated with those described for lineage 1 in Europe and the United States (4). Locally bred and imported horses appeared similarly susceptible to WNV neurologic disease. Younger animals were more likely to be infected, although all age groups had fatalities. Generalized neurologic signs, such as paresis and paralysis with death, positively correlated with WNV infection in horses. Fatal WNV encephalitis was diagnosed in a giraffe at Onderstepoort Veterinary Research (M. Romito, unpub. data), suggesting certain wildlife species in Africa might be more susceptible; however, we did not detect WNVpositive local wildlife in our sample. WNV-induced fetal death was recorded only once, with lineage 1 infection, but should continue to be monitored.

The geographic distribution of WNV is mainly dependent on favorable ecology, rainfall, and competent vectors. The range of Culex univitattus mosquitoes, the predominant WNV vector, correlated with the geographic distribution of equine cases in South Africa (6). The distribution of WNV exposure among horses correlated with that among humans (Figure 2, panels A, B), suggesting horses could serve as sentinels for human risk for WNV disease in South Africa. Horses have low WNV viremia, precluding them from transmitting infections and establishing epidemics in humans; however, those handling horse central nervous system tissue should do so with caution (15). Vaccination before the start of the rainy season could reduce the risk for WNV in horses.

In summary, surveillance for neurologic disease in animals across South Africa showed WNV lineage 2 as the primary cause of annual outbreaks, with high fatality rates in horses. Horses proved to be good sentinels for WNV in Africa and can be used to determine geographic and seasonal risk patterns for human WNV disease.

\section{Acknowledgments}

We thank all veterinarians and animal owners who submitted specimens for this study, as well as the staff members of the Equine Research Centre, University of Pretoria, and Onderstepoort Veterinary Institute; veterinary pathologists who collaborated with us to solve cases; and former research assistants and students. 
The protocol was reviewed and approved by the Department of Agriculture Forestry and Fisheries in terms of Section 20 of the Animal Diseases Act (Act No. 35 of 1984) of South Africa and approved by the University of Pretoria Animal Ethics committee, IRB 00002235 IORG0001762. Funding was provided by cooperative agreement 1U19GH000571-01 with the Global Disease Detection Centre, US Centers for Disease Control and Prevention, Atlanta, Georgia, USA (2013-2015).

Part of this work was funded by the National Research Foundation of South Africa and the National Health Laboratory Services (2008-2012).

Dr. Venter is a professor of medical virology at the Centre for Viral Zoonoses, University of Pretoria, where she heads the Emerging Arbo and Respiratory Virus research group. She specializes in molecular epidemiology and One Health research to investigate zoonotic viruses, particularly neurologic and respiratory viruses, in Africa.

\section{References}

1. Jupp PG. The ecology of West Nile virus in South Africa and the occurrence of outbreaks in humans. Ann N Y Acad Sci. 2001;951: 143-52. http://dx.doi.org/10.1111/j.1749-6632.2001.tb02692.x

2. Petersen LR, Roehrig JT. West Nile virus: a reemerging global pathogen. Emerg Infect Dis. 2001;7:611-4. http://dx.doi.org/ 10.3201/eid0704.017401

3. Danis K, Papa A, Theocharopoulos G, Dougas G, Athanasiou M, Detsis M, et al. Outbreak of West Nile virus infection in Greece, 2010. Emerg Infect Dis. 2011;17:1868-72. http://dx.doi.org/ 10.3201/eid1710.110525

4. Ward MP, Schuermann JA, Highfield LD, Murray KO. Characteristics of an outbreak of West Nile virus encephalomyelitis in a previously uninfected population of horses. Vet Microbiol. 2006;118:255-9. http://dx.doi.org/10.1016/j.vetmic.2006.07.016

5. Ward MP, Scheurmann JA. The relationship between equine and human West Nile virus disease occurrence. Vet Microbiol. 2008;129:378-83. http://dx.doi.org/10.1016/j.vetmic.2007.11.022

6. Burt FJ, Grobbelaar AA, Leman PA, Anthony FS, Gibson GV, Swanepoel R. Phylogenetic relationships of southern African West
Nile virus isolates. Emerg Infect Dis. 2002;8:820-6. http://dx.doi.org/ 10.3201/eid0808.020027

7. Zaayman D, Venter M. West Nile virus neurologic disease in humans, South Africa, September 2008-May 2009. Emerg Infect Dis. 2012;18:2051-4. http://dx.doi.org/10.3201/eid1812.111208

8. Venter M, Human S, Zaayman D, Gerdes GH, Williams J, Steyl J, et al. Lineage 2 West Nile virus as cause of fatal neurologic disease in horses, South Africa. Emerg Infect Dis. 2009;15:877-84. http://dx.doi.org/10.3201/eid1506.081515

9. Bakonyi T, Ivanics E, Erdélyi K, Ursu K, Ferenczi E, Weissenböck H, et al. Lineage 1 and 2 strains of encephalitic West Nile virus, central Europe. Emerg Infect Dis. 2006;12:618-23. http://dx.doi.org/10.3201/eid1204.051379

10. Ward MP, Levy M, Thacker HL, Ash M, Norman SK, Moore GE, et al. Investigation of an outbreak of encephalomyelitis caused by West Nile virus in 136 horses. J Am Vet Med Assoc. 2004;225:84 9. http://dx.doi.org/10.2460/javma.2004.225.84

11. van Eeden C, Swanepoel R, Venter M. Antibodies against West Nile and Shuni viruses in veterinarians, South Africa. Emerg Infect Dis. 2014;20:1409-11. http://dx.doi.org/10.3201/ eid2008.131724

12. van Niekerk S, Human S, Williams J, van Wilpe E, Pretorius M, Swanepoel R, et al. Sindbis and Middelburg old world alphaviruses associated with neurologic disease in horses, South Africa. Emerg Infect Dis. 2015;21:2225-9. http://dx.doi.org/10.3201/eid2112.150132

13. Guthrie AJ, Maclachlan NJ, Joone C, Lourens CW, Weyer CT, Quan M, et al. Diagnostic accuracy of a duplex real-time reverse transcription quantitative PCR assay for detection of African horse sickness virus. J Virol Methods. 2013;189:30-5. http://dx.doi.org/10.1016/j.jviromet.2012.12.014

14. Venter M, Human S, van Niekerk S, Williams J, van Eeden C, Freeman F. Fatal neurologic disease and abortion in mare infected with lineage 1 West Nile virus, South Africa. Emerg Infect Dis. 2011;17:1534-6.

15. Venter M, Steyl J, Human S, Weyer J, Zaayman D, Blumberg L, et al. Transmission of West Nile virus during horse autopsy. Emerg Infect Dis. 2010;16:573-5. http://dx.doi.org/10.3201/ eid1603.091042

Address for correspondence: Marietjie Venter, Centre for Viral Zoonoses, Department Medical Virology, University of Pretoria, PO Box 2034, Pretoria 0001, South Africa; email: marietjie.venter@up.ac.za

\section{World AIDS Day, December 1}

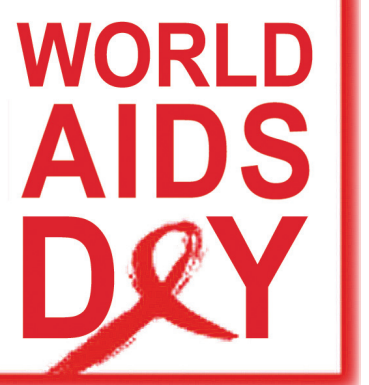

December 1 is World AIDS Day, an opportunity for people to work actively and collaboratively with partners around the world to raise awareness about HIV and help us move closer to the goal of an AIDS-free generation. This year's theme, "The Time to Act Is Now," calls us to act with urgency to implement the latest high-impact, evidencebased HIV prevention strategies.

\section{http://wwwnc.cdc.gov/eid/page/world-aids}

EMERGING INFECTIOUS DISEASES 